\title{
Detecção de possíveis agentes virais associados à circovirose suína*
}

\author{
THAIS FUMACO TEIXEIRA
}

Paulo Michel Roehe (Orientador - UFRGS)

Banca: Paulo Augusto Esteves (EMBRAPA), Odir Antonio Dellagostin (UFPel), Cláudio Wageck Canal (UFRGS)

O Circovírus suíno tipo 2 (PCV2) é um vírus ubíquo que tem sido associado a um número de síndromes em suínos. Entre elas, a Síndrome Multissistêmica do Definhamento dos Suínos (SMDS) tornou-se uma das principais causas de perdas econômicas na suinocultura nacional. No entanto, existe incerteza se o PCV2 é, de fato, o único agente responsável por esse quadro, essencialmente porque a administração isolada do vírus a animais suscetíveis não tem sido capaz de reproduzir experimentalmente a síndrome. Em vista disso, um número de outros agentes infecciosos (e não infecciosos) têm sido examinados e, sua potencial participação no desenvolvimento da SMDS, tem sido pesquisada. No presente estudo foram realizados experimentos visando determinar se outro(s) agente(s) com genoma de DNA circular poderia(m) desempenhar algum papel no desenvolvimento da SMDS. Para tanto, a técnica denominada "amplificação por círculo rolante com múltiplos primers" (ACRMP) foi empregada. A ACRMP é baseada na atividade da DNA polimerase do fago phi29, uma enzima capaz de sintetizar novas moléculas de DNA a partir de um molde de DNA circular. Numa segunda etapa, o DNA amplificado é clivado com enzimas de restrição, ocasionando a linearização de grande quantidade de cópias do DNA alvo original. Como a ACRMP é realizada com primers aleatórios, nenhum conhecimento prévio da seqüência de nucleotídeos alvo é necessário. Portanto, pode-se, teoricamente, amplificar DNA circular de qualquer microorganismo, o que a torna ideal para o propósito do presente estudo. O DNA extraído de soros de 67 suínos com sinais clínicos de SMDS, assim como de 63 suínos saudáveis, foram submetidos à ACRMP. O principal achado deste estudo foi que o genoma de um (ou mais) anelovírus foi(ram) detectado(s) em 88,9\% (56/63) dos suínos saudáveis, ao passo que o(s) mesmo(s) agente(s) somente foi(ram) detectado(s) em 16,4\% (11/67) dos soros de suínos com sinais clínicos da SMDS. Alguns fragmentos de DNA, potencialmente correspondentes a fragmentos de genomas virais, foram seqüenciados, revelando que, pelo menos um deles, corresponde a uma seqüência de anelovírus suíno ainda não descrita. No entanto, outro genoma correspondente a um anelovírus foi encontrado na mesma amostra, sugerindo que mais de um vírus pode estar presente em amostras de soro. Esses resultados demonstraram que os anelovírus, de grande variabilidade genética, são significativamente mais prevalentes em suínos clinicamente saudáveis do que em suínos com SMDS.

Descritores: circovírus suíno, PCV2, SMDS, coinfecção, TTV.

\footnotetext{
*Dissertação de Mestrado n.482 (Especialidade: Virologia). 74f. Programa de Pós-graduação em Ciências Veterinárias [www.ufrgs.br/ppgcv], Faculdade de Veterinária, Universidade Federal do Rio Grande do Sul (UFRGS), Porto Alegre/RS. CORRESPONDÊNCIA: T.F. Teixeira [thaisny_bio@yahoo.com.br].
} 


\title{
Detection of possible viral agents associated with postweaning multisystemic wasting syndrome**
}

\author{
THAIS FUMACO TEIXEIRA
}

\author{
Paulo Michel Roehe (Adviser - UFRGS)
}

Committee: Paulo Augusto Esteves (EMBRAPA), Odir Antonio Dellagostin (UFPel), Cláudio Wageck Canal (UFRGS)

Porcine circovirus type 2 (PCV2) is an ubiquitous virus that has been associated to a number of syndromes in swine. Among these, Postweaning Multisystemic Wasting Syndrome (PMWS) has become a major cause of economic losses in swine worldwide. However, there is uncertainty as to whether PCV2 is in fact the sole agent responsible for the disease, essentially because the disease has not been experimentally reproduced when PCV2 is inoculated onto susceptible animals. In view of that, a number of other infectious (and non infectious) agents have been examined and their potential role in PMWS searched for. This study was carried out to determine whether any other agent(s) with circular DNA genome might be playing some role in PMWS. In order to achieve that, a technique called "randomly primed rolling circle amplification" (RPRCA) was employed. RPRCA is based on the activity of bacteriophage phi29 DNA polymerase, an enzyme that synthesizes new DNA molecules starting from a circularized DNA template. In a second phase, the amplified DNA is cleaved with restriction enzymes, so giving rise to large amounts of linearized copies of the original target DNA. As RPRCA is performed with random priming, no previous knowledge of the target nucleotide sequence is necessary. Therefore, it is theoretically possible to amplify circular DNA of any microorganism, thus making it ideal for the purpose of the present study. DNA extracted from sera of 67 pigs with clinical signs of PMWS as well as from 63 healthy pigs was submitted to RPRCA. The major finding of this study was that the genome of one (or more) anelloviruses was detected in 88,9\% (56/63) of the healthy pigs, whereas the same agent was only detected in 16,4\% (11/67) of pigs with clinical signs of PMWS. Some of the DNA fragments corresponding to the putative virus genomes were sequenced and revealed at least one non-previously described anellovirus sequence. However, other anellovirus could be found on the same sample, suggesting that more than one genome are present in samples of serum. These results demonstrate that anelovírus, of great genetic variability, were significantly more prevalent in healthy pigs than in pigs with PMWS.

Key words: porcine circovirus, PCV2, PMWS, co-infections, TTV.

Presented: 31 January 2008

**Master's Thesis \#482 (Field: Virology). 74p. Graduate Program in Veterinary Sciences[www.ufrgs.br/ppgcv], Faculdade de Veterinária, Universidade Federal do Rio Grande do Sul (UFRGS), Porto Alegre/Brazil. CORRESPONDENCE: T.F. Teixeira [thaisny_bio@yahoo.com.br]. 